\title{
Penerapan Rule-Based Expert System (RBES) Dalam Perancangan Aplikasi Sistem Pakar Untuk Mendiagnosa Penyakit Infeksi Saluran Pernapasan Akut (ISPA) Berbasis Android
}

\author{
Nisaul Fadila ${ }^{1}$, Rinabi Tanamal ${ }^{2}$ \\ ${ }^{1,2}$ Universitas Ciputra Surabaya, Indonesia \\ 1Email: nisaulfadilaa@gmail.com, ${ }^{2}$ Email: r.tanamal@ ciputra.ac.id
}

\begin{abstract}
ABSTRAK. Banyak orang yang sering menganggap bahwa penyakit ISPA adalah penyakit ringan, padahal penyakit ISPA memiliki tingkat bahaya yang cukup tinggi khususnya mereka yang memiliki kekebalan daya tubuh rendah. ISPA merupakan kelompok penyakit yang disebabkan oleh infeksi dari virus dan telah menyerang saluran pernapasan seperti paru-paru, hidung, serta tenggorokan. Penelitian mengenai diagnosis penyakit ISPA menggunakan metode Rule-based Expert System (RBES), dan akan menghasilkan sistem pakar diagnosa ISPA berdasarkan berbagai gejala yang dirasakan oleh pengguna. Sistem pakar ini menggunakan basis android dengan dibuat pada software bernama Thunkable. Berdasarkan hasil dari pengujian tingkat penerimaan aplikasi oleh pengguna, diperoleh angka sebesar $96 \%$ untuk aspek kemudahan dalam penggunaan dan $93 \%$ untuk aspek kemudahan dalam memahami fitur/menu dalam aplikasi. Tidak hanya itu, pengujian keakurasian juga dilakukan dan aplikasi sistem pakar yang dibuat dan dikembangkan memiliki tingkat akurasi sebesar $100 \%$.
\end{abstract}

Kata Kunci: Sistem Pakar; Rule-Based Expert System (RBES); Infeksi Saluran Pernapasan Akut (ISPA); Thunkable; Android.

\begin{abstract}
Many people often assume that ARI is a mild disease, even though ARI has a fairly high level of danger, especially those who have low immune systems. ARI is a group of diseases caused by viral infections and has attacked the respiratory tract such as the lungs, nose, and throat. This ARI diagnosis research uses the RBES method, and will produce an expert system for diagnosing ARI based on various symptoms felt by the user. This expert system uses an Android base built on software called Thunkable. Based on the results of testing the level of acceptance of the application by the user, the figure is $96 \%$ for the ease of use aspect and $93 \%$ for the ease of understanding the features/menus in the application. Not only that, accuracy testing is also carried out and the expert system application created and developed has a $100 \%$ accuracy rate.
\end{abstract}

Keywords: Expert System; Rule-Based Expert System (RBES); Acute Respiratory Infections (ARI); Thunkable; Android.

\section{PENDAhuluan}

Infeksi Saluran Pernapasan Akut atau yang biasa disebut ISPA merupakan kelompok penyakit kompleks yang menyerang saluran pernapasan pada manusia dan disebabkan oleh berbagai faktor penyebabnya. (Yuliana, Paradise, \& Kusrini, 2018) Salah satu penyebab dari ISPA adalah virus seperti Rotavirus, Influenza, bakteri Streptococcus Pneumoniae, dan bakteri Staphylococcus Aureus. (Yuliana, Paradise, \& Kusrini, 2018) Organisasi WHO menyebutkan, ISPA adalah penyebab atau faktor utama dari mortalitas serta morbiditas penyakit menular di dunia. Hampir 4 juta orang mengalami kematian akibat ISPA setiap tahunnya. Penyakit ISPA juga merupakan salah satu kelompok penyakit yang cukup umum terjadi di masyarakat khususnya masyarakat Indonesia. (Ramadhani, Fitri, \& Handayani, 2020)

Di kondisi yang sekarang ini, banyak masyarakat yang memilih untuk mendiagnosis sendiri dan melakukan penanganan sendiri terkait penyakit yang sering dialami tanpa harus perlu mengunjungi dokter ataupun tanpa perlu pengawasan dokter. Pada kenyataannya, penyakit ISPA perlu diagnosa dokter serta pengawasan dokter. Tetapi, dengan berkembangnya teknologi dan ilmu pengetahuan, membuat banyak kegiatan manusia yang dapat dilakukan oleh teknologi dengan dibantu ilmu pengetahuan, salah satunya adalah sistem pakar. Dengan begitu, masyarakat tidak perlu mengunjungi dokter, tetapi tetap bisa mendapat diagnosis dan juga pengawasan dari dokter melalui perantara sistem pakar tersebut.

Saat ini banyak hal yang sudah berubah ketika teknologi telah diperbarui secara terus-menerus dan juga telah memberikan pengalaman yang baik bagi sebagian besar orang. (Tanamal, 2019) Salah satunya sistem pakar seperti ini dengan dibuat menjadi sebuah aplikasi. Sistem pakar ini nantinya dapat memberikan diagnosa kepada para pengguna terkait penyakit ISPA. 
Sistem pakar bermulai pada istilah knowledge-based expert system. Sistem tersebut muncul digunakan untuk memecahkan suatu masalah, sedangkan sistem pakar bekerja dengan menggunakan pengetahuan dari seorang pakar yang kemudian diinputkan dalam komputer. Sistem pakar memiliki struktur, yaitu : (Sinaga, Hasugian, \& Manurung, 2018)

1. Knlowdege Base

2. Inference Engine

3. User Interface

Dalam penelitian ini metode Rule-Based Expert System (RBES) digunakan untuk dapat memberikan hasil diagnosis penyakit ISPA secara akurat dalam suatu aplikasi sistem pakar yang dapat dipergunakan untuk masyarakat umum yang membutuhkan aplikasi tersebut. Rule-Based Expert System (RBES) adalah suatu sistem pakar dengan menggunakan aturan / kaidah (rules) yang berfungsi untuk dapat merepresentasikan suatu pengetahuan yang ada dalam basis pengetahuan tersebut. (Amroni, 2016)

Suatu sistem dengan menggunakan basis aturan (rule) yang terdiri dari sekelompok fakta, aturan $I F$ THEN. Seorang penerjemah yang dapat mengontrol penerapan terhadap aturan tersebut berdasar fakta yang ada. Aturan tersebut dapat direpresentasikan dengan 'Jika A adalah 1, maka B adalah 2'. Bagian aturan 'A adalah 1' yang disebut dengan premis atau anteseden, sedangkan bagian lainnya 'B adalah 2' disebut dengan kesimpulan atau konsekuensi. (Rakhmawati, et al., 2018) Aplikasi yang dibuat nantinya akan menggunakan basis android yang akan dapat digunakan oleh masyarakat umum karena memiliki akses yang lebih mudah dengan smartphone mereka. Android adalah platform terbuka (open source) bagi para programmer / pengembang aplikasi. (Mutia, Triyanto, \& Ilhamsyah, 2016)

\section{METODOLOGI PENELITIAN}

Tahapan penelitian ini diawali dari mengidentifikasi masalah-masalah yang berkaitan dengan penilitian. Kemudian dilakukan pengumpulan data dan informasi terkait seluruh hal yang dibutuhkan untuk penelitian, selain itu melakukan studi literatur untuk mempelajari proses perancangan desain aplikasi sistem mulai dari penggunaan metode hingga melakukan testing penggunaan aplikasi kepada para pengguna. Sebelum itu dilakukan olah data hasil wawancara untuk menjadi phohon keputusan. Perancangan aplikasi sistem pakar diagnosis penyakit Infeksi Saluran Pernapasan Akut (ISPA) menggunakan metode rule-based expert system dengan dasar pohon keputusan yang menggunakan teknik forward chaining yang disusun dengan menggunakan software $M c G o o$.

\section{Perancangan Sistem}

Desain Arsitektur Sistem

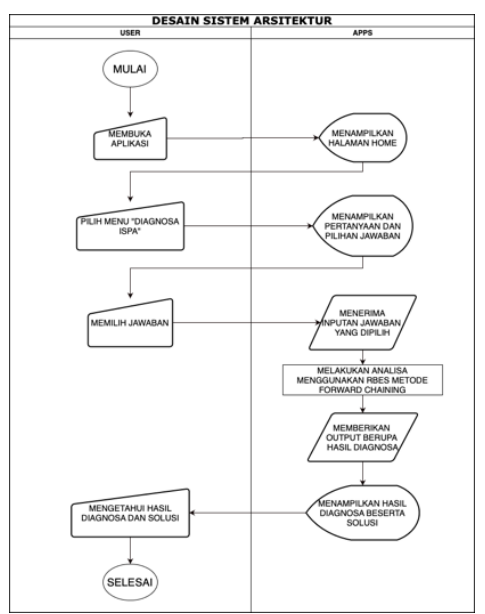

Gambar 1. Desain Sistem Arsitektur

Dari gambar di atas, dapat dijelaskan bahwa cara kerja / cara penggunaan aplikasi sistem pakar dalam mendiagnosa penyakit ISPA adalah :

1. Pengguna menggunakan aplikasi untuk dapat mengatahui penyakit yang sedang di derita yang termasuk ke dalam jenis ISPA berdasarkan beberapa gejala yang telah ditanyakan pada aplikasi sistem pakar tersebut.

2. Aplikasi tersebut berisi beberapa pertanyaan seputar gejala terkait penyakit ISPA yang telah ditentukan berdasarkan decision tree / pohon keputusan yang nantinya dapat dipilih oleh user sesuai 
dengan kondisi yang dialami. Pertanyaan yang telah dijawab oleh user akan diproses dalam sistem pakar sehingga akan diberikan hasil diagnosa penyakit dan user dapat mengetahui penyakit ISPA apa yang sedang diderita.

User Interface

User Interface aplikasi ISPA Detector memiliki fitur :

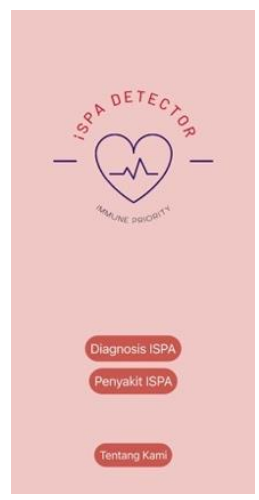

Gambar 2. User Interface Halaman Utama

1. Halaman awal pada aplikasi ISPA Detector merupakan halaman menu yang menampilkan logo ISPA Detector beserta 3 pilihan menu. Halaman Home / Menu adalah halaman utama yang berisikan menumenu / fitur-fitur yang disediakan dalam aplikasi ISPA Detector.

2. Tampilan dibawah ini merupakan tampilan halaman diagnosis berupa pertanyaan-pertanyaan seputar gejala yang dialami dan harus dijawab oleh user, dari pertanyaan yang ditampilkan user harus memberikan jawaban antara "YA" dan "TIDAK".

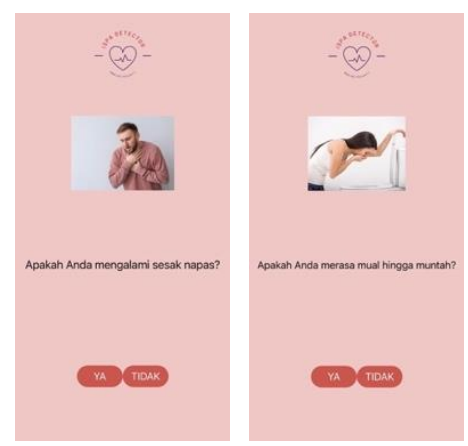

Gambar 3. User Interface Halaman

3. Tampilan dibawah ini merupakan tampilan halaman hasil diagnosa penyakit yang dihasilkan dari beberapa pertanyaan diagnosis sebelumnya. Halaman hasil diagnosa memberikan penjelasan penyakit yang dialami terkait hasil diagnosa yang telah didapat oleh user.

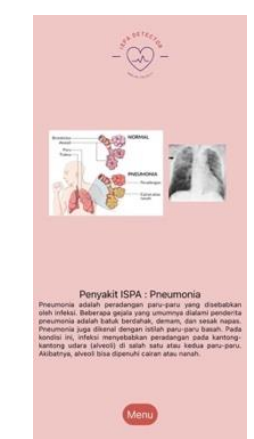

Gambar 4. User Interface Halaman Diagnosa

4. Tampilan dibawah ini merupakan tampilan halaman pengetahuan yang berisikan pengetahuan / edukasi terkait penjelasan penyakit ISPA itu sendiri. 


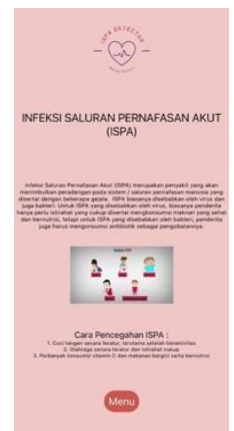

Gambar 5. User Interface Halaman Penyakit ISPA

5. Halaman akhir pada aplikasi ISPA Detector adalah halaman Tentang Kami. Halaman ini berisikan penjelasan terkait aplikasi ISPA Detector beserta pakar yang merupakan dasar pengetahuan aplikasi dan juga sumber informasi.

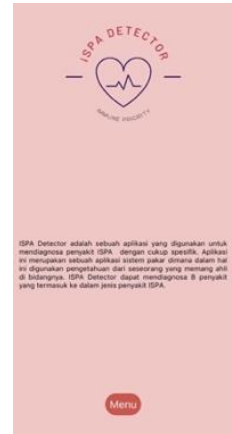

Gambar 6. User Interface Halaman Tentang Kami

\section{Implementasi}

Tahap awal dalam melakukan pengimplementasian sistem pakar adalah wawancara bersama pakar. Wawancara tersebut akan menghasilkan sebuah informasi baru dimana hasil dari wawancara dengan pakar tersebut yang akan diolah Kembali dan menjadi sebuah decision tree. Decision tree atau yang juga disebut pohon keputusan dibuat dengan tujuan sebagai dasar ataupun inti pengetahuan yang dapat menunjang berjalannya sebuah aplikasi sistem pakar. Berikut merupakan pertanyaan yang disusun dalam pembuatan decision tree, yaitu :

1. Apakah Anda mengalami sesak napas?

2. Apakah Anda merasa mual hingga muntah?

3. Apakah Anda merasa pilek?

4. Apakah hidung Anda mengeluarkan cairan kental berwarna kuning kehijauan?

5. Apakah Anda mengalami kesulitan saat menelan makanan / minuman?

6. Apakah Anda merasa terjadi pembesaraan amandel dan terlihat lebih merah dibanding biasanya?

7. Apakah Anda mengalami nyeri tenggorokan?

8. Apakah suara Anda serak / parau

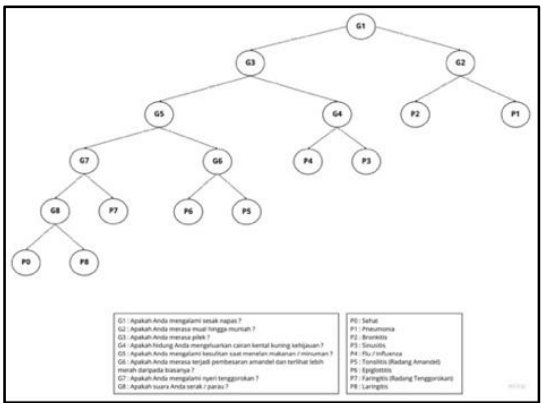

Gambar 7. Decision Tree / Pohon Keputusan 
Daftar Penyakit

Tabel 1. Daftar Penyakit

\begin{tabular}{|c|c|c|c|}
\hline No. & Kode & Gejala & Keterangan \\
\hline 1. & G1 & $\begin{array}{l}\text { Apakah Anda mengalami } \\
\text { sesak napas? }\end{array}$ & $\begin{array}{l}\text { [Ya] Lanjut ke gejala G2 } \\
\text { [Tidak] Lanjut ke gejala G3 }\end{array}$ \\
\hline 2. & G2 & $\begin{array}{l}\text { Apakah Anda merasa mual } \\
\text { hingga muntah? }\end{array}$ & $\begin{array}{l}\text { [Ya] Lanjut ke hasil diagnosa P1 } \\
\text { [Tidak] Lanjut ke hasil diagnosa P2 }\end{array}$ \\
\hline 3. & G3 & Apakah Anda merasa pilek? & $\begin{array}{l}\text { [Ya] Lanjut ke gejala G4 } \\
\text { [Tidak] Lanjut ke gejala G5 }\end{array}$ \\
\hline 4. & G4 & $\begin{array}{l}\text { Apakah hidung Anda } \\
\text { mengeluarkan cairan kental } \\
\text { berwarna kuning kehijauan? }\end{array}$ & $\begin{array}{l}\text { [Ya] Lnjut ke hasil diganosa P3 } \\
\text { [Tidak] Lanjut ke hasil diagnsosa P4 }\end{array}$ \\
\hline 5. & G5 & $\begin{array}{l}\text { Apakah Anda mengalami } \\
\text { kesulitan saat menelan } \\
\text { makanan / minuman? }\end{array}$ & $\begin{array}{l}\text { [Ya] Lanjut ke gejala G6 } \\
\text { [Tidak] Lanjut ke gejala G7 }\end{array}$ \\
\hline 6. & G6 & $\begin{array}{l}\text { Apakah Anda merasa terjadi } \\
\text { pembesaran amandel dan } \\
\text { terlihat lebih merah daripada } \\
\text { biasanya? }\end{array}$ & $\begin{array}{l}\text { [Ya] Lanjut ke hasil diagnosa P5 } \\
\text { [Tidak] Lanjut ke hasil diagnosa P6 }\end{array}$ \\
\hline 7. & G7 & $\begin{array}{l}\text { Apakah Anda mengalami } \\
\text { nyeri tenggorokan? }\end{array}$ & $\begin{array}{l}\text { [Ya] Lanjut ke hasil diagnosa P7 } \\
\text { [Tidak] Lanjut ke gejala G8 }\end{array}$ \\
\hline 8. & G8 & $\begin{array}{l}\text { Apakah suara Anda serak / } \\
\text { parau? }\end{array}$ & $\begin{array}{l}\text { [Ya] Lanjut ke hasil diagnosa P8 } \\
\text { [Tidak] Lanjut ke hasil diagnosa P0 }\end{array}$ \\
\hline
\end{tabular}

Decision tree yang telah dibuat oleh peneliti akan disusun lagi dan diimplementasikan dalam aplikasi McGoo sehingga menjadi ES-Builder. Decision tree yang dibuat di aplikasi McGoo disusun dengan 3 tahapan yaitu dengan menggunakan "Attribute", "Value", dan juga "Conclusion". Dalam hal ini, proses penyusunannya akan mengimplementasikan metode forward chaining. Tahapan attribute berisikan pertanyaan daripada gejala yang telah disebut dalam decision tree. Tahapan value berisi jawaban pertanyaan dari tahapan attribute dengan 2 pilihan jawaban yaitu "YA" atau "TIDAK". Tahapan conclusion berisikan hasil diagnosa yang dihasilkan sesuai dengan yang ada pada decision tree.

Decision tree yang telah dibuat dan juga telah disusun ke dalam McGoo akan dirancang serta diimplementasikan pada aplikasi berbasis mobile apps Android menggunakan aplikasi Thunkable. Thunkable digunakan untuk dapat merancang aplikasi ISPA Detector. Penggunaan Thunkable untuk merancang aplikasi dianggap dapat memudahkan perancangan bagi peneliti dan juga lebih praktis, karena fitur-fitur yang disediakan oleh Thunkable hanya drag and drop, dan juga Thunkable merupakan aplikasi open source yang dapat digunakan secara umum serta gratis.

\section{HASIL DAN PEMBAHASAN}

Uji Akurasi

Pada pengujian ini, pohon keputusan (decision tree) yang telah disusun berdasarkan gejala serta diagnosis penyakit akan dibandingkan dengan hasil diagnosis dari pakar yang didapat dari hasil wawancara. Tidak hanya itu, kesesuaian, ketepatan, serta keakurasiannya akan diuji juga terhadap aplikasi sistem pakar yang telah selesai dirancang. Dari ketiga komponen / aspek tersebut akan dilakukan pembandingan dan penyesuaian agar dapat diketahui hasil keakurasiannya.

Tabel 2. Hasil Uji Akurasi

\begin{tabular}{|c|c|c|c|c|}
\hline No. & Gejala & $\begin{array}{c}\text { Hasil Diagnosa } \\
\text { Aplikasi }\end{array}$ & $\begin{array}{c}\text { Hasil Diganosa } \\
\text { Pakar }\end{array}$ & $\begin{array}{c}\text { Sesuai atau Tidak } \\
\text { Sesuai }\end{array}$ \\
\hline 1. & $\begin{array}{l}\text { Sesak napas, mual } \\
\text { dan muntah }\end{array}$ & Pneumonia & Pneumonia & Sesuai \\
\hline 2. & Sesak napas & Bronkitis & Bronkitis & Sesuai \\
\hline 3. & $\begin{array}{l}\text { Pilek, keluar cairan } \\
\text { kental kuning } \\
\text { kehijauan }\end{array}$ & Sinusitis & Sinusitis & Sesuai \\
\hline
\end{tabular}




\begin{tabular}{lllll}
\hline 4. & Pilek & Influenza & Influenza / Flu & Sesuai \\
\hline 5. & $\begin{array}{l}\text { Sulit menelan, } \\
\text { pembesaran amandel } \\
\text { dan amandel } \\
\text { memerah }\end{array}$ & $\begin{array}{l}\text { Tonsilitis (Radang } \\
\text { Amandel) }\end{array}$ & $\begin{array}{l}\text { Tonsilitis (Radang } \\
\text { Amandel) }\end{array}$ & Sesuai \\
\hline 6. & Sulit menelan & Epiglottitis & Epiglottitis & Sesuai \\
\hline 7. & Nyeri tenggorokan & $\begin{array}{l}\text { Faringitis (Radang } \\
\text { Tenggorokan) }\end{array}$ & $\begin{array}{l}\text { Faringitis (Radang } \\
\text { Tenggorokan) }\end{array}$ & Sesuai \\
\hline 8. & $\begin{array}{l}\text { Nyeri tenggorokan, } \\
\text { suara parau }\end{array}$ & Laringitis & Laringitis & Sesuai \\
\hline
\end{tabular}

Uji User Acceptance Testing (UAT)

Selain uji akurasi, dilakukan juga pengujian dalam hal penerimaan aplikasi oleh pengguna. Pada pengujian ini, akan dilakukan percobaan oleh pengguna terhadap aplikasi system pakar sekaligus menjawab kuesioner yang telah dibuat dengan 5 pertanyaan sesuai dengan aspek pengujian UAT. Aplikasi ini diuji kepada 21 orang pengguna sebagai sampel responden penelitian ini. Pengujian UAT ini menggunakan metode skala likert dengan nilai 1-5, dengan angka 5 adalah nilai tertinggi dari pengujian ini. Pengujian UAT ini menghasilkan total skor sebagai berikut :

Tabel 3. Hasil Total Skor Uji UAT

\begin{tabular}{|c|c|c|c|c|c|c|}
\hline \multirow[t]{2}{*}{ No. } & \multirow[t]{2}{*}{ Pertanyaan } & \multicolumn{5}{|c|}{ Penilaian user } \\
\hline & & 12 & 3 & 4 & 5 & $\begin{array}{l}\text { Total } \\
\text { Skor }\end{array}$ \\
\hline 1. & $\begin{array}{l}\text { Apakah } \\
\text { aplikasi } \\
\text { ISPA } \\
\text { Detector } \\
\text { mudah } \\
\text { digunakan? }\end{array}$ & & & 4 & 17 & 101 \\
\hline 2. & $\begin{array}{l}\text { Apakah fitur } \\
\text { / menu } \\
\text { dalam } \\
\text { aplikasi } \\
\text { ISPA } \\
\text { Detector } \\
\text { mudah } \\
\text { dipahami? }\end{array}$ & & & 7 & 14 & 98 \\
\hline 3. & $\begin{array}{l}\text { Apakah } \\
\text { tampilan } \\
\text { aplikasi } \\
\text { ISPA } \\
\text { Detector } \\
\text { menarik? }\end{array}$ & & 6 & 9 & 6 & 90 \\
\hline 4. & $\begin{array}{l}\text { Apakah } \\
\text { informasi } \\
\text { terkait ISPA } \\
\text { serta gejala } \\
\text { ISPA yang } \\
\text { diberikan } \\
\text { oleh aplikasi } \\
\text { ISPA } \\
\text { Detector }\end{array}$ & & & 10 & 11 & 94 \\
\hline
\end{tabular}




\begin{tabular}{|c|c|c|c|c|}
\hline & $\begin{array}{l}\text { sesuai / } \\
\text { tepat? }\end{array}$ & & & \\
\hline 5. & $\begin{array}{l}\text { Apakah } \\
\text { aplikasi } \\
\text { ISPA } \\
\text { Detector } \\
\text { bermanfaat } \\
\text { bagi Anda? }\end{array}$ & 13 & 17 & 100 \\
\hline
\end{tabular}

Dengan hasil perhitungan total skor seperti pada table diatas, maka pengujian User Accepptance Testing (UAT) memiliki hasil nilai persentase tiap pertanyaan sebagai berikut :

Tabel 4. Hasil Uji UAT

\begin{tabular}{|c|c|c|c|}
\hline No. & Pertanyaan & Nilai & Keterangan \\
\hline 1. & $\begin{array}{l}\text { Apakah aplikasi } \\
\text { ISPA Detector } \\
\text { mudah } \\
\text { digunakan? }\end{array}$ & $96 \%$ & $\begin{array}{l}\text { Sangat } \\
\text { Setuju }\end{array}$ \\
\hline 2. & $\begin{array}{l}\text { Apakah fitur / } \\
\text { menu dalam } \\
\text { aplikasi ISPA } \\
\text { Detector mudah } \\
\text { dipahami? }\end{array}$ & $93 \%$ & $\begin{array}{l}\text { Sangat } \\
\text { Setuju }\end{array}$ \\
\hline 3. & $\begin{array}{l}\text { Apakah tampilan } \\
\text { aplikasi ISPA } \\
\text { Detector } \\
\text { menarik? }\end{array}$ & $80 \%$ & $\begin{array}{l}\text { Sangat } \\
\text { Setuju }\end{array}$ \\
\hline 4. & $\begin{array}{l}\text { Apakah informasi } \\
\text { terkait ISPA serta } \\
\text { gejala ISPA yang } \\
\text { diberikan oleh } \\
\text { aplikasi ISPA } \\
\text { Detector sesuai / } \\
\text { tepat? }\end{array}$ & $90 \%$ & $\begin{array}{l}\text { Sangat } \\
\text { Setuju }\end{array}$ \\
\hline 5. & $\begin{array}{l}\text { Apakah aplikasi } \\
\text { ISPA Detector } \\
\text { bermanfaat bagi } \\
\text { Anda? }\end{array}$ & $95 \%$ & $\begin{array}{l}\text { Sangat } \\
\text { Setuju }\end{array}$ \\
\hline
\end{tabular}

\section{KESIMPULAN DAN SARAN}

Berdasarkan pada proses panjang yang telah dilalui, telah menghasilkan beberapa poin kesimpulan dalam penelitian yang dilakukan. Perancangan dan penyusunan aplikasi sistem pakar berbasis android dilakukan dengan berdasar pada pengetahuan yang diambil dari decision tree / pohon keputusan yang kemudian akan diimplementasikan ke dalam apps builder software yang bernama Thunkable dengan menggunakan metode Forward Chaining. Aplikasi sistem pakar yang telah dirancang memiliki kemampuan untuk mendiagnosa penyakit Infeksi Saluran Pernapasan Akut (ISPA) dengan berdasar pada kelimuan serta pengetahuan pakar. Aplikasi ISPA Detector memiliki hasil analisa dengan 96\% mudah digunakan, 93\% mudah dipahami, $80 \%$ untuk tampialn user interface, $90 \%$ memiliki kesesuaian informasi, dan $95 \%$ dapat bermanfaat untuk pengguna.

Saran perluasan untuk dapat mengembangkan aplikasi ISPA Detector yaitu dapat menambah jumlah jenis penyakit ISPA yang dapat didiagnosa lebih banyak dan bervariasi serta dapat menambahkan solusi dan pengobatan kepada pengguna setelah hasil diagnosa keluar supaya pengguna lebih cepat untuk mengambil tindakan setelahnya. 


\section{DAFTAR RUJUKAN}

Afdal, M., \& Humani, D. G. (2020, Februari). Aplikasi Sistem Pakar Diagnosa Awal Penyakit Menular Pada Balita Berbasis Android. Jurnal Ilmiah Rekayasa dan Manajemen Sistem Informasi, 6(1), 55-63.

Amroni. (2016, April). Penerapan Sistem Pakar Berbasis Rule Dalam Pembagian Zakat Menurut Hukum Islam. Jurnal Ilmiah Media Processor, 11(1).

Anam, M. K., \& Anggraini, L. (2016). Meningkatkan Literasi Perbankan Syariah Dengan Mengembangkan Aplikasi Edukasi Berbasis Android. JUST IT : Jurnal Sistem Informasi, Teknologi Informatika, dan Komputer, 10(2).

Marlina, M., Saputra, W., Mulyadi, B., Hayati, B., \& Jaroji. (2017, Mei). Aplikasi Sistem Pakar Diagnosis Penyakit ISPA Berbasis Speech Recognition Menggunakan Metode Naive Bayes Classifier. Jurnal Teknologi informasi \& Komunikasi Digital Zone, 8(1), 58-70.

Mutia, A., Triyanto, D., \& Ilhamsyah. (2016). Sistem Pakar Untuk Mendiagnosa Penyakit Pada Sistem Pernafasan Menggunakan Metode Forward Dan Backward Chaining. Jurnal Coding, Sistem Komputer Untan, 4(3), 119-128.

Putra, C. D. (2017, Maret). Sistem Pakar Diagnosa Penyakit ISPA (Infeksi Saluran Pernapasan Akut) Menggunakan Metode Certainty Factor Berbasis Web. JATI (Jurnal Mahasiswa Teknik Informatika), 1(1).

Rakhmawati, N. A., Budi, A. S., Atletiko, F. J., Hindrayani, K. M., Ramadhani, F., \& Handayani, S. F. (2018, November). Penentuan Prioritas Pengambilan Pesanan Barang Oleh Angkutan Kota Dengan Metode Rule-Based System. Jurnal Sistem Informasi Bisnis 02, 8(2), 195-202.

Ramadhani, T. F., Fitri, I., \& Handayani, E. T. (2020, Mei). Sistem Pakar Diagnosa Penyakit ISPA Berbasis Web Dengan Metode Forward Chaining. JOINTECS (Journal of Information Technology and Computer Science), 5(2), 81-90.

Sinaga, B., Hasugian, P., \& Manurung, A. M. (2018, Maret). Sistem Pakar Mendiagnosa Kerusakan Smartphone Android Menggunakan Metode Certainty Factor. Journal of Informatic Pelita Nusantara, 3.

Takapente, C. B., Sompie, S. R., \& Poekoel, V. C. (2018). Implementasi Azure Cognitive Service Untuk Aplikasi Pengkategorian Foto. E-Journal Teknik Informatika, 13(4).

Tanamal, Rinabi. (2019, Oktober). What is the most influential factor on decisions using youtube as a tool to supportbuy or sell means? (case study surabaya city and surrounding area) JATIT (Journal of Theoretical and Applied information Technology). 97(20).

Yuliana, Paradise, \& Kusrini. (2018, Juni). Sistem Pakar Diagnosa Penyakit Ispa Menggunakan Metode Naive Bayes Classifier Berbasis Web. 128. CSRID Journal, 10(3), 127-138. 